\title{
The Competition Way of the Senior Citizen's Newspaper Development
}

\author{
Liu Bowei \\ Mianyang Teachers’ College, Mianyang, Sichuan, China, 621000
}

Keywords: old age publication; segmentation; wide audiences; specialty

\begin{abstract}
The competition strategy of the aged newspaper market in the past 30 years has been to catch the audience's preference, subdivide the columns, subdivide the sections and even subdivide the periodicals to meet the needs of the audience. This paper takes old age publication in China as an example, analyzes the competition way of old age publication, namely the specialty formed with the distinctive creation quality, to develop new products and services, thus in the competition to win more core competitiveness, and realize the development and cultivation of the broad masses.
\end{abstract}

\section{Introduction}

Old newspapers and the development of older publications lock older audiences, through the sub-headings and sub-department to meet the needs of readers to gain the newspaper market. Market segmentation is the combination of customer preference and product characteristics, in this combination, it is necessary to create an overwhelming opponent's competitive advantage in order to win more audiences. This requires that in addition to satisfying customer preference, the old newspaper must create uniqueness, develop new products and services, and thus cover more audiences in the competition.

\section{To Create Unique, Developed Expertise}

"Old Age newspaper" from the inception to now has more than 30 years of development history, it is as old-age media, first of all, the passing on the news philosophy that than competing media arrives at the hands of the audience for "fast" to overcome the old media news lack of timeliness of flaws. It was in the middle of the 80 's, in the characteristics of the positioning of the "people have no I have" this card, it has a unique health care, medical services and firmly grasp the reader.

"Sunset" magazine in the early days of the national exclusive introduction of the interactive section poetry. By professionals to develop miniature poems, couplets competition, to the topic of the members of the poetry, all the readers can participate in the recruitment. The such unique typesetting way is more advantageous to the poem association amateur search and reading. Such a unique column will not only Sichuan, Chongqing, Yunnan, Guizhou and other land readers attracted, but also Shandong, Jilin, Guangzhou and other poetry lovers pulled over, but also for those well-known writers, poets to provide a platform, but also for the "Sunset" magazine itself to enhance visibility.

In the old age magazine also has the origination semimonthly publication precedent, like "the Chinese Old age Study" magazine each month is A, B two, "Sunset glow Newspaper" as well as "the Chinese Old Annual report" even a week all must leave four times and more number of times, but they only were hold the content the volume to increase, in style still same. In order to promote market-oriented degree, "Sunset" magazine first launched fortnightly, will originally run the magazine for 20 years as the first half of the month, with other senior magazine's head. The second half of the first in the country political newspapers, determined to create the first national old political magazine, which become the "sunset" magazine and the absolute uniqueness. The second half of the month to change the black and white layout of the printing mode, instead of full color version, good quality of coated paper, but also in the second half of the month set up "The World", "Fresh News", "Hot Focus", "work Information", "Learning Reference", "Confidential File", "Classic reading", "New bookshelf" and other columns. This allows the magazine itself to 
accommodate more people of different ages and cultures, making it a competitive advantage in the competition of the same kind of old age newspapers and developing a wide audience. In the $90 \mathrm{~s}$, the congener and newspaper appeared in all parts of the country "you have I have to introduce each other familiar layout for eight years," LaoNianBao "launch" health weekly ", "travel the world" and "famous", "soft touch" and so on the new features and new flashed out "people have me," this card. Following closely, also sizes up the situation in new old century in turn time, enhances strong points and avoid weaknesses, had decided "also is especially special when my him" not yet completely appears, immediately revealed "human I am especially quick" this sign. The "old Age" is also published every day in the news version of a number of people from all over the country belonging to the elderly concerned with group-proximity information, and in the "News Collection" column published three to five from a wide range of concise news. At the same time, the introduction of "Amorous Russia" special edition, so that older people more in-depth understanding of the world's sexual events and characters.

Not only that, but also "tour the World", "Global Expo", "Newspaper Digest" and other special editions of the contents of the further expansion, so that the "old Age newspaper" information close to the beginning of an unprecedented group proximity to the main body, to the field of proximity, regional proximity for the wings, mutual cooperation, there is the main from the pattern, the formation of $1+1+1>3$ aggregation effect. "Sunset" magazine in 2007, the creation of fine "serial" column, the selection of modern history, such content not only the elderly love, but also a large part of young and middle-aged educated intellectuals are particularly loved. And at the end of 2006, the introduction of "Educated Youth archives", mainly on the occurrence in that special background deeds. Therefore, the uniqueness of media creation, that is, the media expertise, it can meet the audience than competitors, the formation of the core competitiveness of the media.

\section{The Development of New Products or Services}

From the older newspaper column or content to meet the needs of older readers and often is not enough, there is also a need for readers to develop new and better products or services. As a large number of elderly groups of health care products demand is very large, so there is a lot of old people on the market, but many products are not high quality, reputation is not protected, so the elderly health care products market is very confusing. "Fall Light" the magazine company and the strength strong main item helping the poor enterprise group company cooperates develops the old person healthy product. Develops the senior citizen demand product specially, took "Fall Light" the magazine characteristic product pushes to the market, sells outright its right of management, defers to the senior citizen to need to adjust the formula and the packing, and gives the pledge safeguard to the product quality, recommends gives the reader, has received reading public's welcome.

Chinese Old age Association sponsors "the Chinese Old age" vigorously supported and positively participated in "the blade of grass parental affection advisory service center" the activity. They mainly provide health counseling and services for the elderly, and also set up a "Silver Age advocacy group. "The members of the center have come to various streets for many times and have successfully organized the "old-age health" public forum activities in different communities. They also "help old one pair with the advanced age and the spatial nest old person sign one" the service agreement and exchange the compassion card, the volunteer enter "help old one pair one" the family, has carried on the exchange in view of old person's daily life and the ordinary day leisure activity. "Respect old love old help old big theme activities" publicity and education performances after the drama, the volunteers also conducted on-site education and training, the old love to help the old idea of the discussion. Therefore, the "old age" magazine and the "Shuncha Counseling Service Center" in fact, the whole society to respect the old mutual use of the actual action of the right direction of public opinion. Heilongjiang "Old age" is the only daily newspaper in the old age, it has sponsored and hosted the "First ten Chinese senior People's news selection" activities. The event's experts and judges are from the national public coverage of more than 10 screening of the elderly, deeds outstanding, worthy China's 130 million elderly representatives. The "Top Ten seniors" were 
selected to take part in a trip to Harbin, organized by the old Age newspaper. As a result of January Harbin or the world of ice and snow, such climate is very easy to let the old person body leave the condition. "Old Annual report" has striven for the Harbin Medical college affiliated hospital medical care personnel's entire journey accompaniment, and has also provided the compassion physical examination service for the old people. This newspaper also greatly enhanced it through the active organization in to receive in the numerous hearts the medium image.

\section{Conclusion}

The old age publication developed the new product and the service both has met reader's needs, and has promoted the publication overall image, set up the bigger medium image in certain region or the nationwide scale, this went to other media compared to the flowered high price to make the advertisement the effect to come well, was more advantageous to the raise the audiences to the old age medium loyalty and the high viscosity.

\section{References}

[1] Zhang Li Weit: "Media Competition Principle and Tool". Qinghua University publishing house, 2007 edition, 16th page.

[2] Chen Qiulan: "Educated youth Climbs Mountains Descends a mountain Movement and China's Urbanized Development". "Party history Research and Teaching". 2004 years 4th issue, 43-46th page.

[3] Ding Zhuangyi "Listens attentively to "Sound Which Silent Community Sends out”", "China Studies Newspaper" .2006 year 5th issue, 25th page. 